Supporting information for

\title{
Development of a Fluorescent Probe for Measurement of Singlet Oxygen Scavenging Activity of Flavonoids
}

Darina Pronin, ${ }^{\dagger}$ Saarangan Krishnakumar, ${ }^{\S}$ Michael Rychlik, ${ }^{\dagger}$ Haixia $\mathrm{Wu}^{*}{ }^{\ddagger}, \S$ and Dejian Huang*,

${ }^{\ddagger}$ Department of Chemistry, College of Chemistry and Chemical Engineering, Inner Mongolia University, Hohhot 010021, People's Republic of China

${ }^{\S}$ Department of Food Science and Technology, National University of Singapore, 3

Science Drive 3, Singapore 117543, Republic of Singapore

${ }^{\dagger}$ Analytical Food Chemistry, Technical University of Munich, Maximus-von-Imhof-

Forum 2, D-85354 Freising, Germany

${ }^{*}$ Corresponding author

Haixia Wu. E-mail: chmwuhx@imu.edu.cn

Dejian Huang. E-mail: chmhdj@nus.edu.sg 
Table S1. The final concentration solutions of antioxidants in PBS buffer.

\begin{tabular}{|c|c|c|}
\hline Antioxidant ${ }^{a}$ & Stock solution $\mathrm{mg} / \mathrm{mL}$ & Final concentration $\mu \mathrm{g} / \mathrm{mL}$ \\
\hline Vitamin C & 3.63 & $5.3 / 24.5 / 62.9 / 126 / 205.5 / 274$ \\
\hline Trolox in $\mathrm{MeOH}$ & 2.40 & $17.5 / 35 / 52.5 / 70 / 87.5 / 95$ \\
\hline$\beta$-Carotene in $\mathrm{MeOH}$ & 1.07 & $5.6 / 56 / 84 / 112 / 140 / 168$ \\
\hline Caffeic acid in $\mathrm{MeOH}$ & 0.99 & 0.5 / $6.1 / 12.3 / 18.3$ / 24.5 / 36.7 \\
\hline Epicatechin in DMSO & 0.96 & 0.5 / 6.8 / 2.7 / 13.7 / 27.4 / 41.1 \\
\hline Catechin gallate & 0.19 & $0.54 / 1.1 / 1.4 / 2.7 / 4.1 / 5.4$ \\
\hline Epigallocatechin & 0.67 & $0.4 / 0.9 / 1.9$ / $4.8 / 13.9 / 19.2$ \\
\hline Epigallocatechin galatte & 0.98 & $0.2 / 0.3 / 0.5 / 1.1 / 1.4 / 2.2$ \\
\hline Myricetin in DMSO & 0.64 & $0.4 / 1.3 / 1.8 / 2.7 / 3.6 / 5.5$ \\
\hline Quercetin in DMSO & 0.60 & $0.9 / 1.7 / 2.1 / 2.3 / 2.6 / 3.5$ \\
\hline Kaempferol in DMSO & 0.57 & $2.2 / 2.5 / 2.9 / 3.8 / 5.0 / 5.7$ \\
\hline
\end{tabular}

${ }^{a}$ The following stock solutions were prepared in deionized water, unless otherwise described.

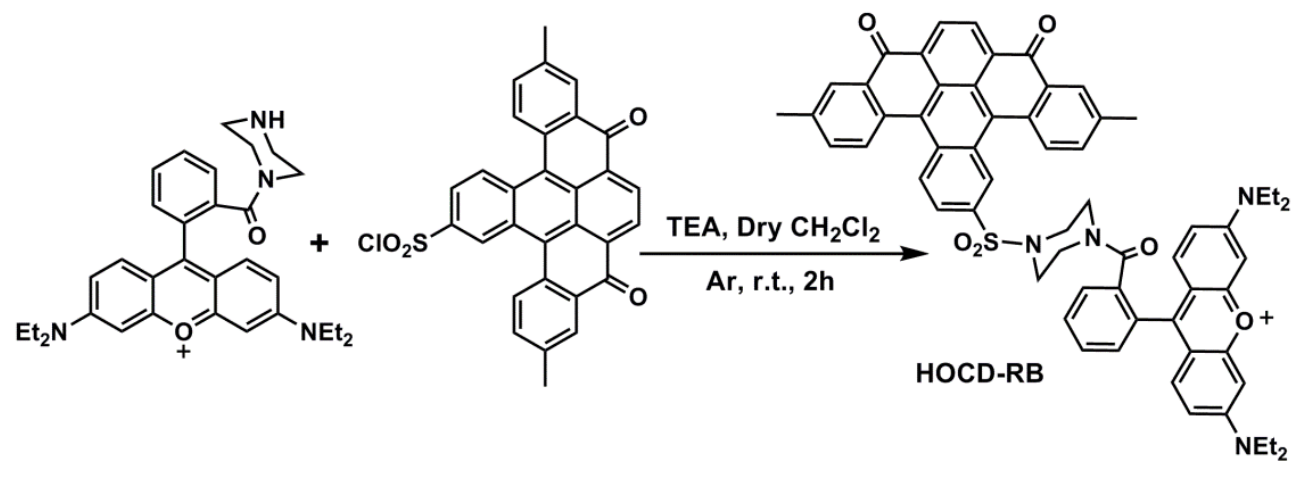

Scheme S1. Synthesis of probe HOCD-RB. 

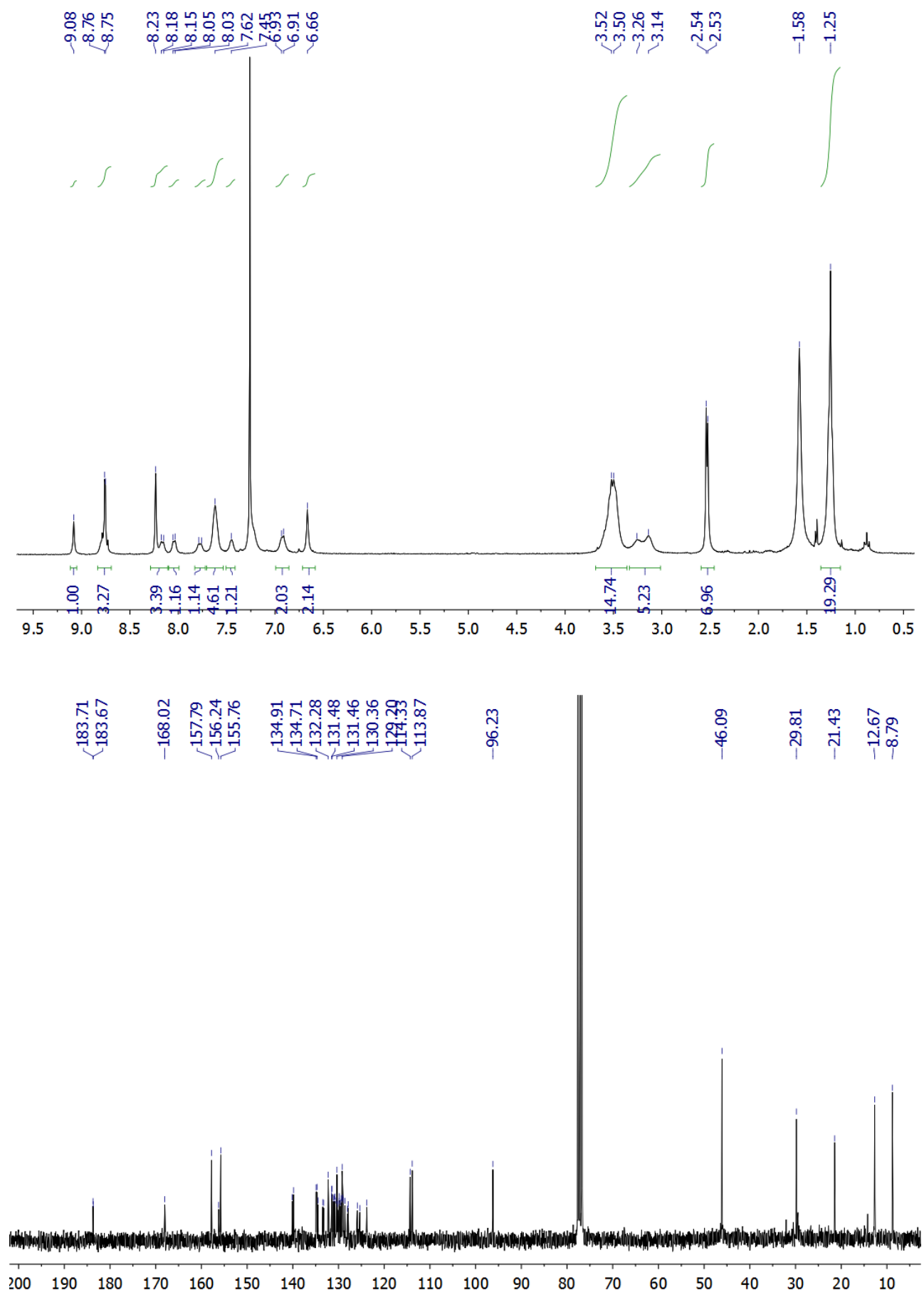

Figure S1. ${ }^{1} \mathrm{H}-\mathrm{NMR}$ and ${ }^{13} \mathrm{C}-\mathrm{NMR}$ spectra of HOCD-RB. 


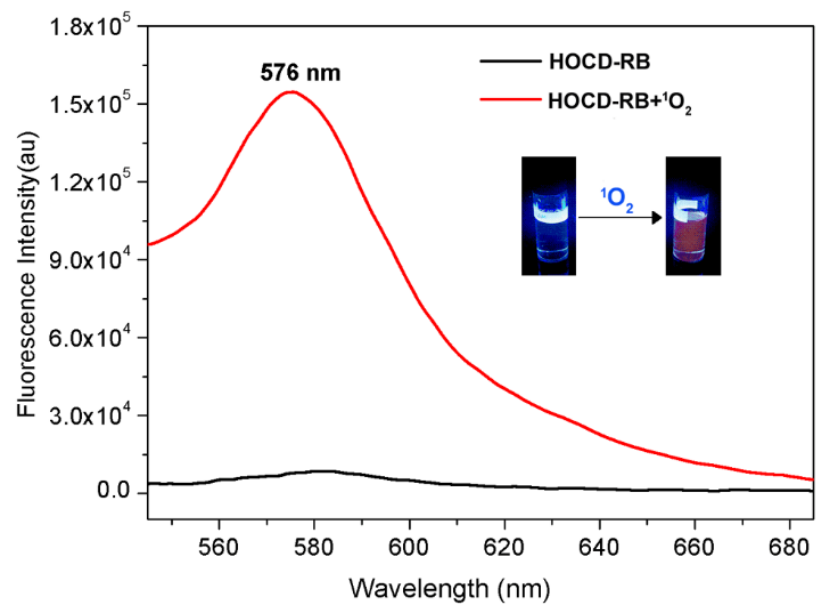

Figure S2. The fluorescence emission spectra of HOCD-RB $(0.1 \mu \mathrm{M})$ delivered using 20 equiv DOTAP in $10 \mathrm{mM}$ PBS buffer (pH 7.4), in the presence or absence of ${ }^{1} \mathrm{O}_{2}$ for 10 min at r.t. $\left(\lambda_{\mathrm{ex}}=480 \mathrm{~nm}\right) .{ }^{1} \mathrm{O}_{2}$ is generated by photo-irradiation of rose Bengal.

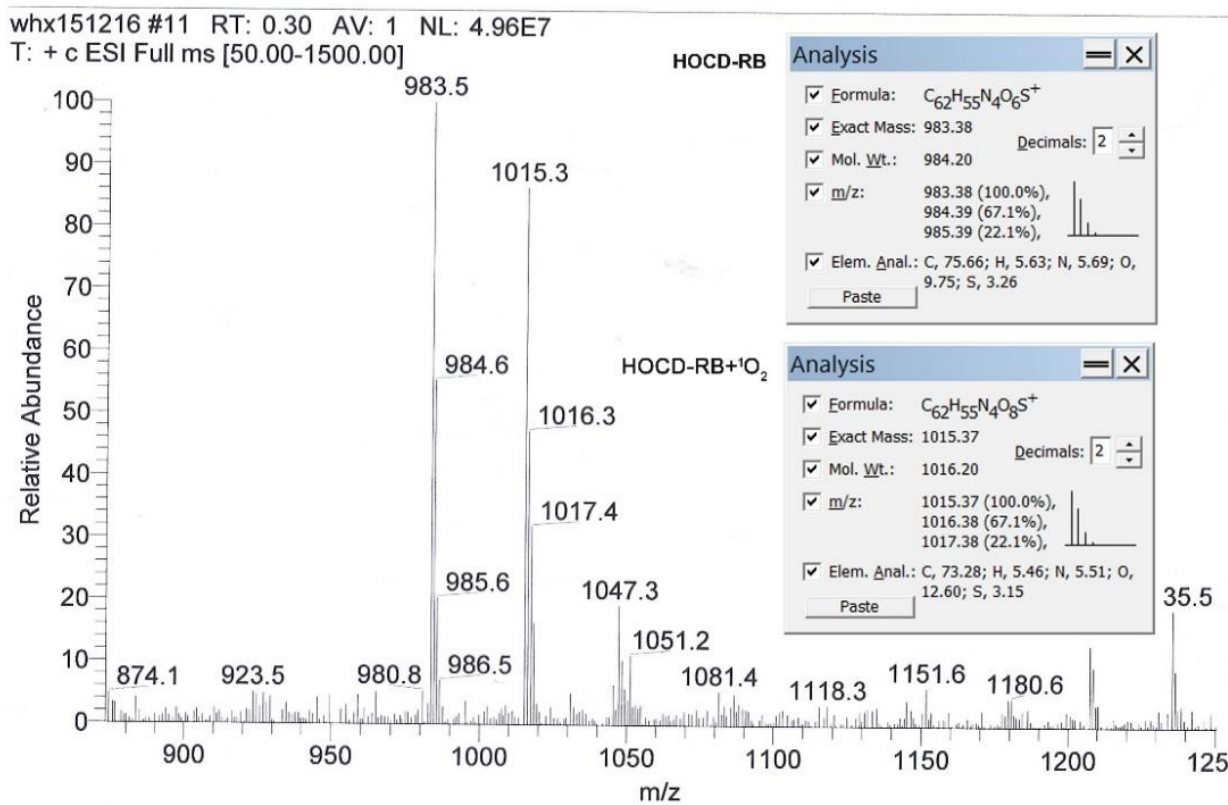

Figure S3. ESI-MS of endoperoxide obtained from the reaction of HOCD-RB with ${ }^{1} \mathrm{O}_{2}$ in $10 \mathrm{mM}$ PBS buffer (pH 7.4). 


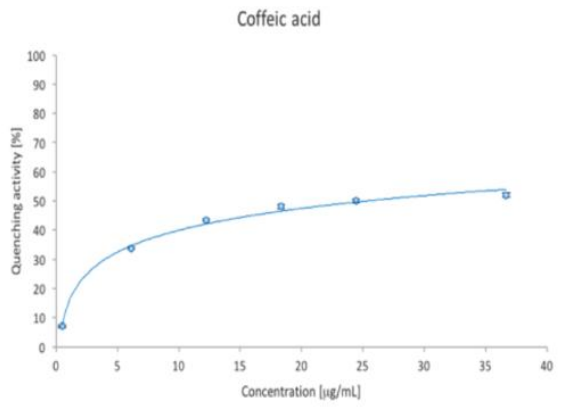

B-Carotene
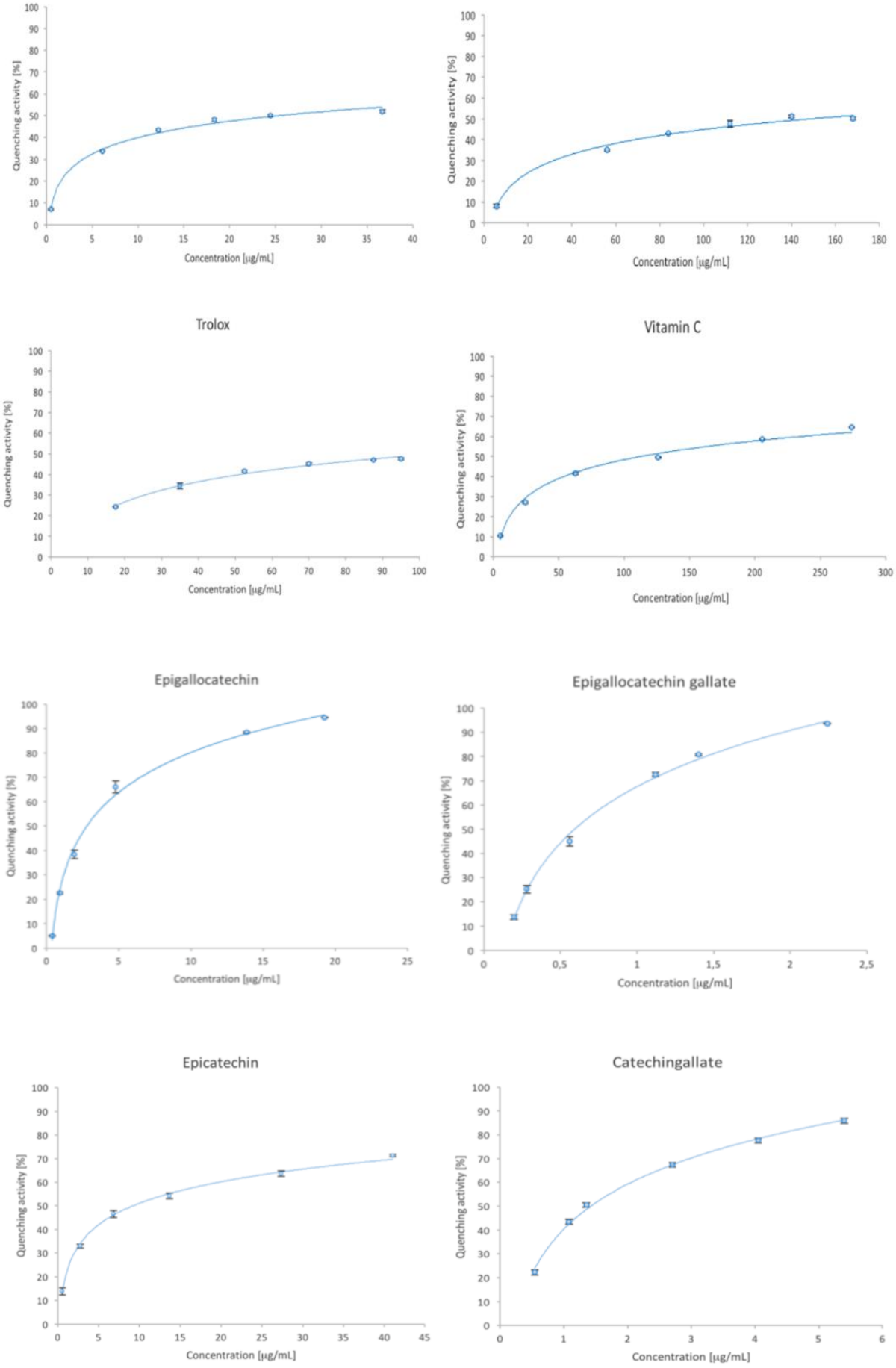

5 

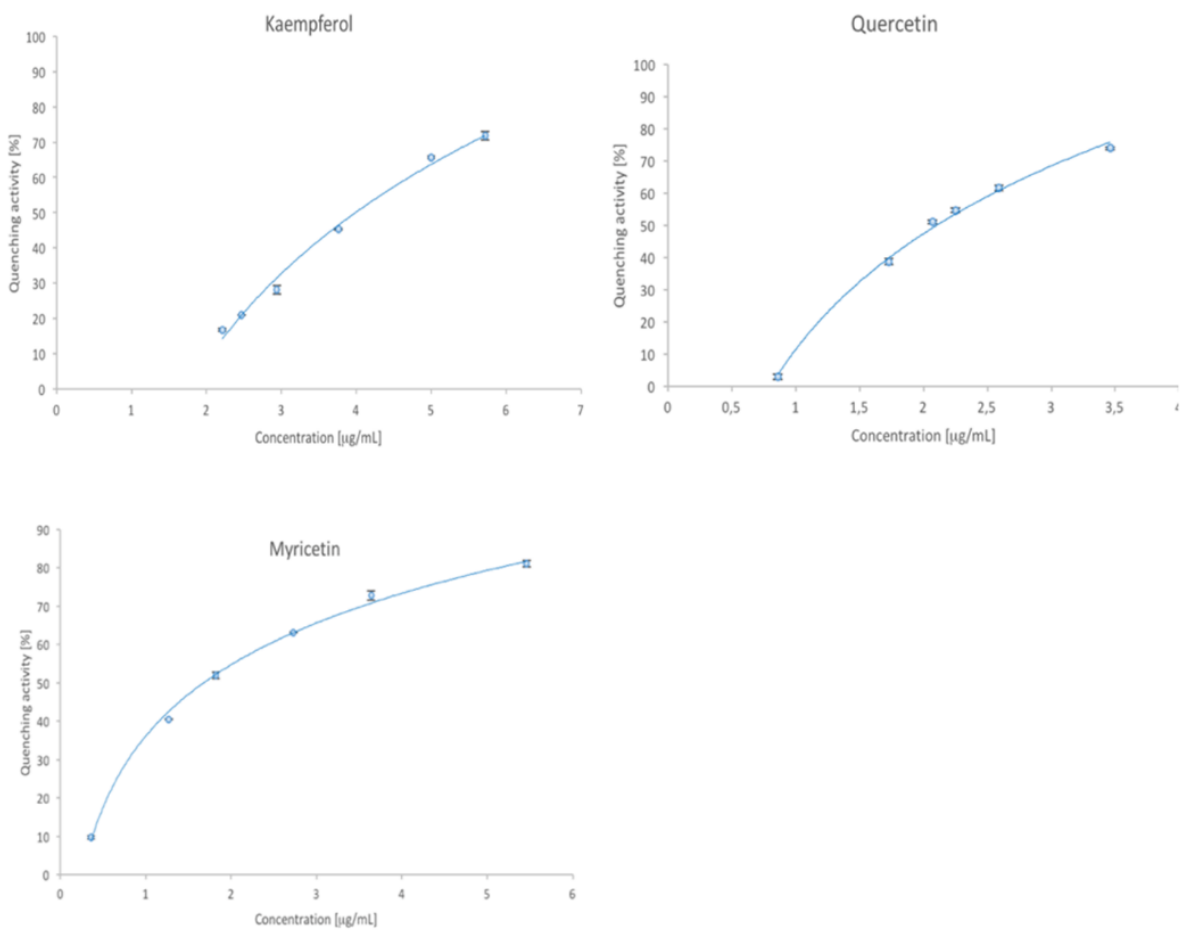

Figure S4. Dose response curves of antioxidants. Error bars represent means $(n=3) \pm$ standard deviation.

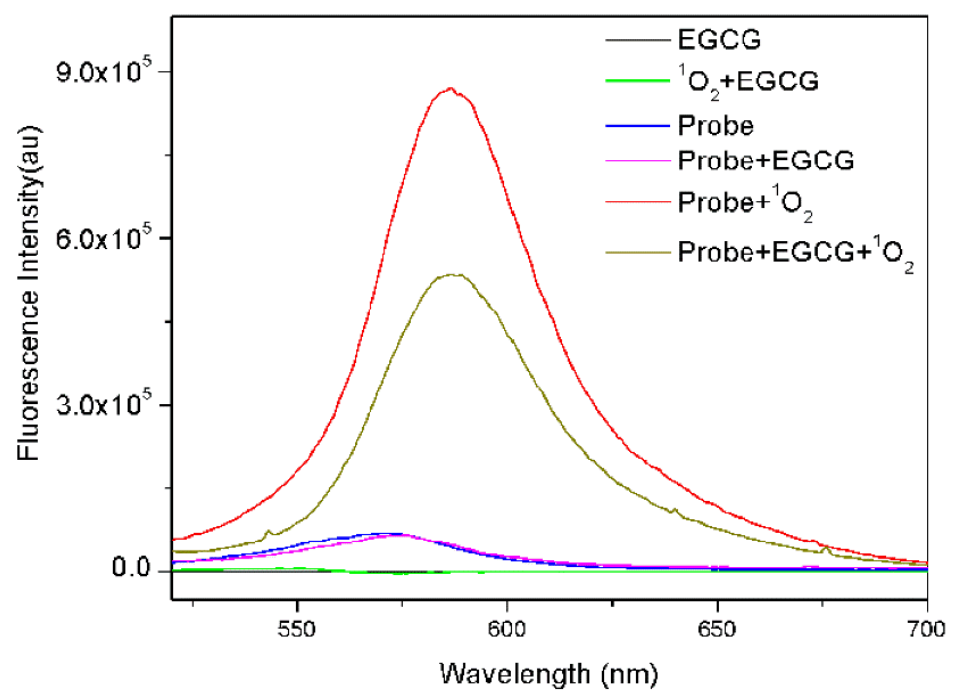

Figure S5. The fluorescence emission spectra of samples consist of ECGC with or without ${ }^{1} \mathrm{O}_{2}$ or probe in $100 \mathrm{mM}$ PBS buffer $\left(\mathrm{pH} 6.8, \lambda_{\text {ex }}=500 \mathrm{~nm}\right)$. 
Table S2. Synergistic effects of flavonoids mixture (1:1 molar ratio), n=3.

$\begin{array}{lll}\text { Mixture (1:1) } & \text { SE } & \text { Effect } \\ \text { EGCG + K } & 0.66 \pm 0.04 & \text { Antagonistic } \\ \text { EGCG + Q } & 0.82 \pm 0.02 & \text { Antagonistic } \\ \text { EGCG + M } & 0.45 \pm 0.05 & \text { Antagonistic } \\ \text { CG }+\mathrm{K} & 1.18 \pm 0.05 & \text { Synergistic } \\ \mathrm{CG}+\mathrm{Q} & & \text { Additive } \\ \mathrm{EC} & & \\ \mathrm{EGC}+\mathrm{M} & & \text { Antagonistic }\end{array}$

${ }^{a}$ No significant difference between experimental and theoretical quenching value $\mathrm{p}<0.01$. 


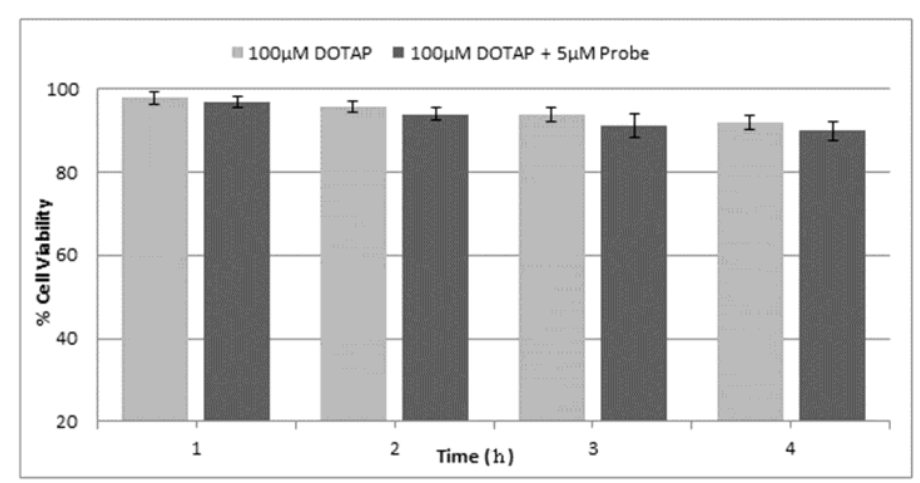

Figure S6. Cytotoxicity effects of HOCD-RB-DOTAP treatment on RAW 264.7 cells. RAW 264.7 cells were treated with $5 \mu \mathrm{M}$ probe $+100 \mu \mathrm{M}$ DOTAP mixture or $100 \mu \mathrm{M}$ DOTAP alone for $4 \mathrm{~h}$, the cell viability was measured using MTT assay. Data were presented as mean \pm SDE of 3 independent experiments.

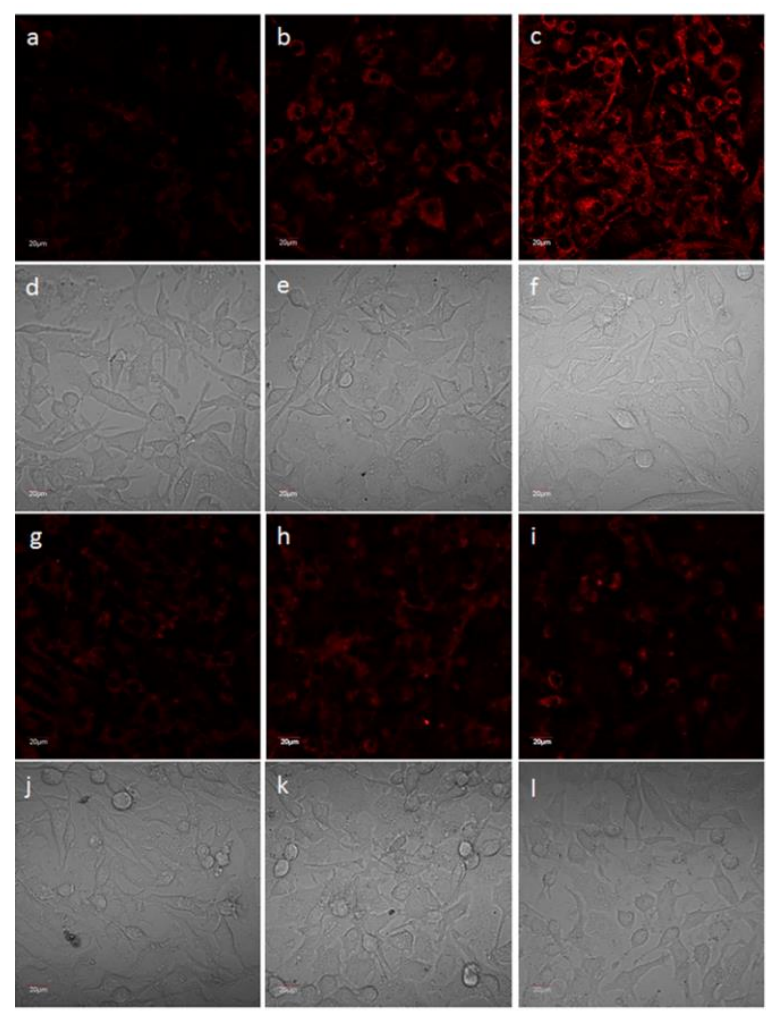

Figure S7. The 2D fluorescent images of cells treated with HOCD-RB $(5 \mu \mathrm{M})$ for 30 min. (a) HOCD-RB alone as control, that is non-stimulated with PMA; (b) and (c) stimulated with PMA (5 and $10 \mu \mathrm{M})$; (g) histidine (400 $\mu \mathrm{M})$ pre-treatment followed by PMA stimulation $(10 \mu \mathrm{M})$; (h) EGC $(100 \mu \mathrm{M})$ pre-treatment followed by PMA stimulation $(10 \mu \mathrm{M})$; (i) EGCG $(100 \mu \mathrm{M})$ pre-treatment followed by PMA stimulation. $\mathrm{d}-\mathrm{f}$ and $\mathrm{j}-\mathrm{l}$ are corresponding DIC images. 


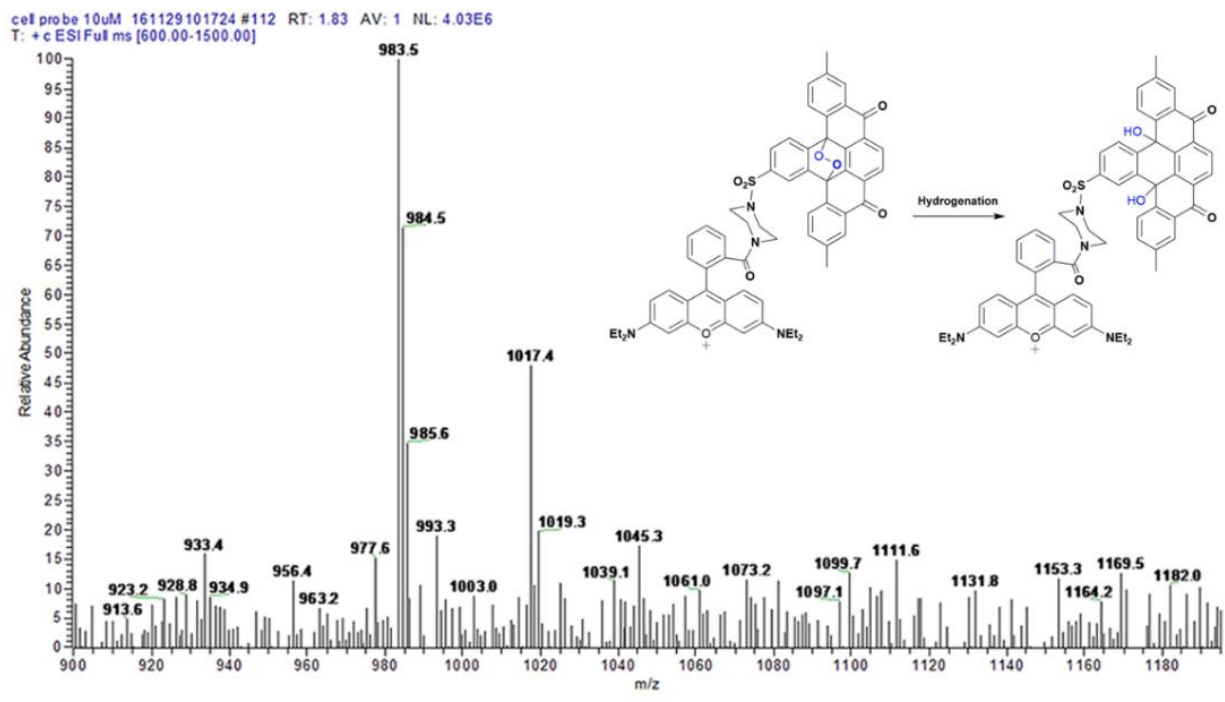

Figure S8. ESI-MS of the products obtained from HOCD-RB reacted with ${ }^{1} \mathrm{O}_{2}$ in cells.
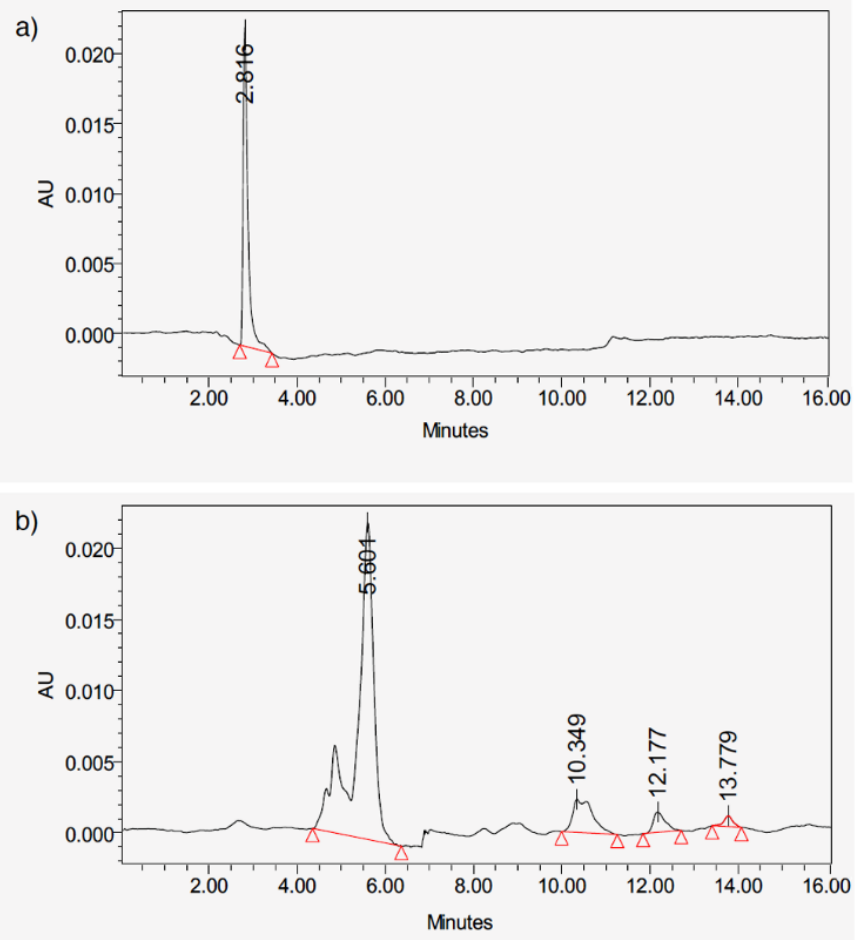

Figure S9. HPLC spectra of EGCG with rose Bengal before (a) and after (b) irradiation. 


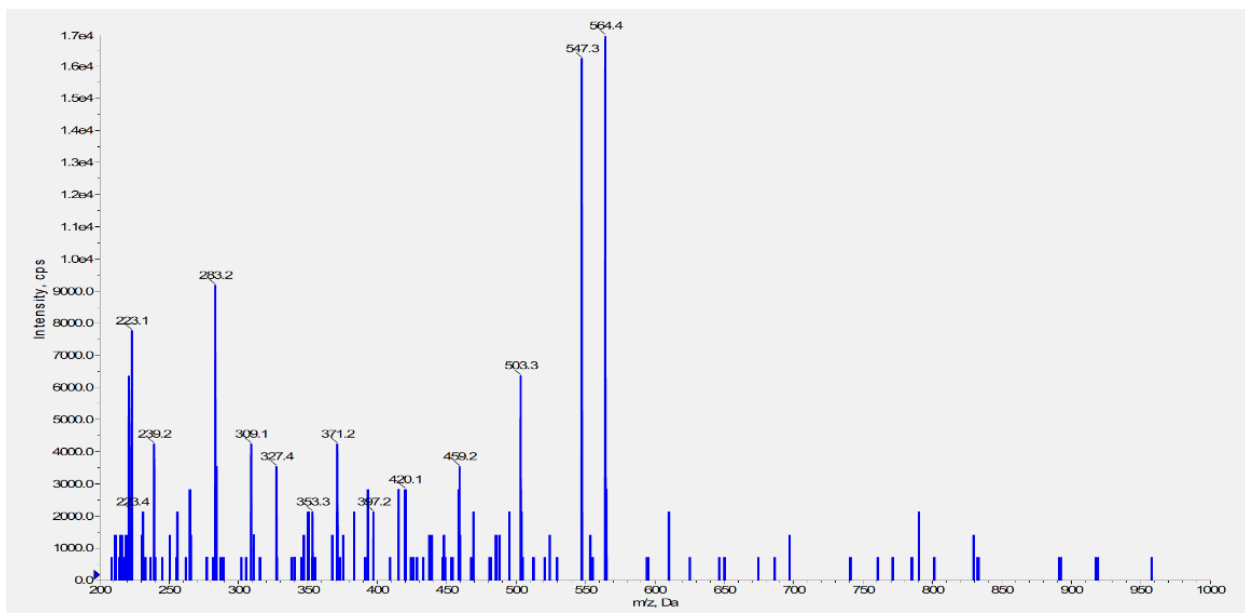

Figure S10. LC-MS/MS spectrum of oxidation product of EGCG with the retention time at $13.78 \mathrm{~min}$ and $\mathrm{m} / \mathrm{z} 564.4$.
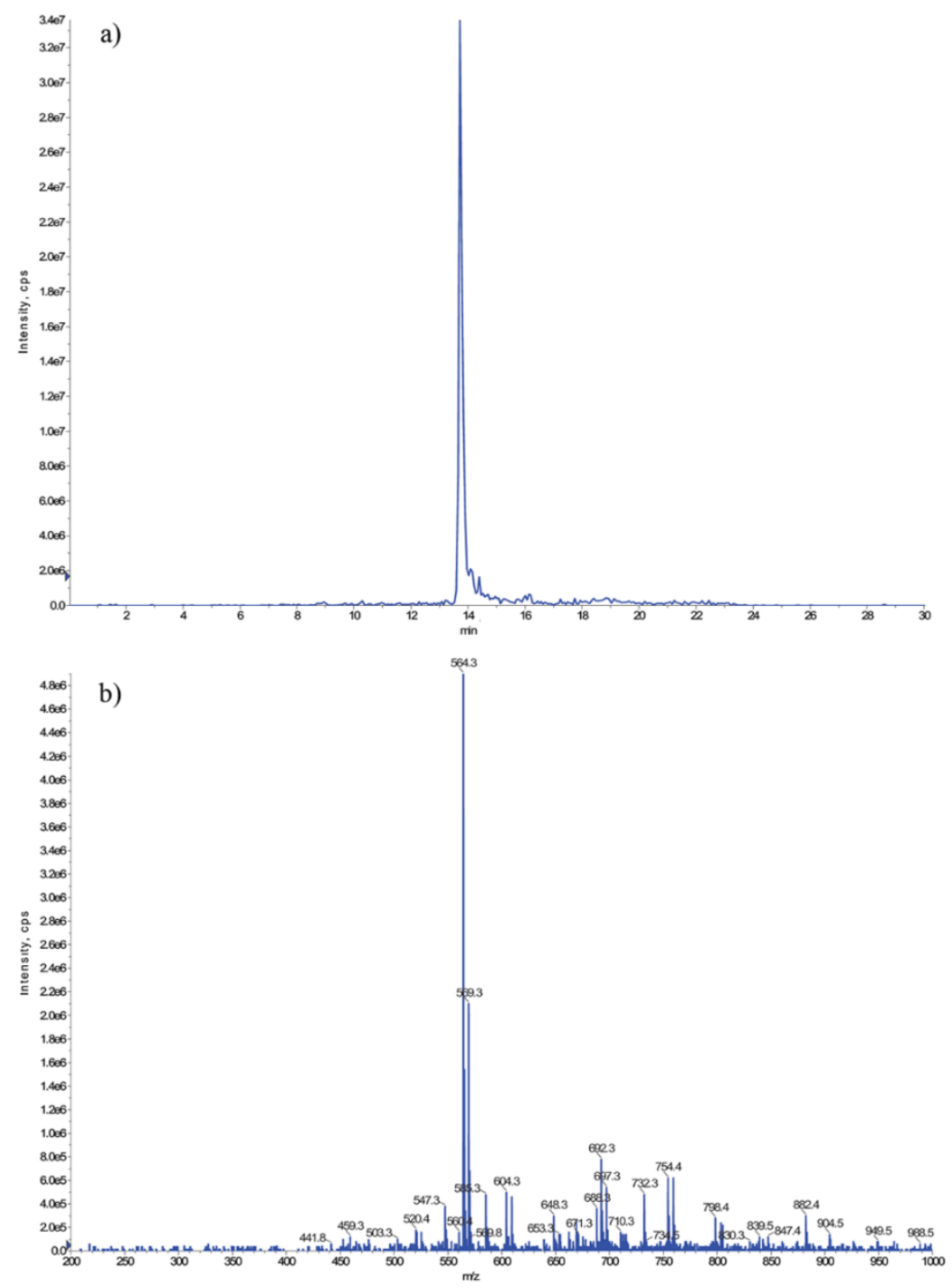

Figure S11. Theaflavine standard LC chromatogram (a) and mass spectrum (b). 